M. A. Noordzij - G. J. van Steenbrugge

T. H. van der Kwast · F. H. Schröder

\title{
Neuroendocrine cells in the normal, hyperplastic and neoplastic prostate
}

Received: 20 June 1994 / Accepted: 10 August 1994

\begin{abstract}
Neuroendocrine cells can be demonstrated in normal, hyperplastic and neoplastic prostatic tissues. The products secreted by these cells can be used as tissue and/or serum markers but may also have biological effects. Neuroendocrine cells in prostate cancer most probably do not contain the androgen receptor and are therefore primarily androgen independent. Some of the neuropeptides secreted by the neuroendocrine cells may act as growth factor by activation of membrane receptors in an autocrine-paracrine fashion or by ligand-independent activation of the androgen receptor in neighboring non-neuroendocrine cells. Evidence is accumulating from experiments with tumor models that neuropeptides indeed can influence the growth of prostatic tumor cells. Future research on neuroendocrine differentiation may answer some questions concerning the biological behavior of clinical prostatic tumors.
\end{abstract}

Key words Neuroendocrine differentiation - Prostate Neoplasm - Androgen sensitivity - Neuropeptide Experimental models

In most developed countries prostate cancer has become the most prevalent tumor in men and in these countries its mortality is only surpassed by that due to lung cancer [74, 106]. Much research done in the field of prostate cancer is directed towards the identification of factors involved in tumor progression and the change from androgen dependency towards independency. Neuroendocrine differentiation is a possible factor which has received increasing attention during the past few years [74].

M. A. Noordzij (雨) - G. J. van Steenbrugge · F. H. Schröder

Department of Urology, room EE 1000 ,

Division of Urological Oncology, Erasmus University,

PO Box 1738, NL-3000 DR Rotterdam, The Netherlands,

Fax: +31 (10) 4366928

T. H. van der Kwast

Department of Pathology, Erasmus University,

NL-3000 DR Rotterdam, The Netherlands
Neuroendocrine (NE) cells are also known as APUD (amine precursor uptake and decarboxylation) cells or endocrine-paracrine cells [77]. The concept of NE/APUD cells was worked out by Pearse and coworkers from the diffuse endocrine epithelial organ concept of Feyrter [42, 77]. The APUD system consists of a group of apparently unrelated endocrine cells located in endocrine and non-endocrine tissues, which share a number of cytochemical, ultrastructural and functional characteristics [77]. In more detail, the endocrine/NE system consists of: the classical endocrine organs (e.g., adrenals, parathyroid gland), clusters of endocrine cells (e.g., pancreatic islets of Langerhans), dispersed epithelial endocrine cells (e.g., gastrointestinal NE cells), neurons and ganglia and the paraganglion system [39].

The clinical aspects of NE differentiation in prostatic carcinoma have been reviewed in more detail in a number of papers by Di Sant'Agnese [30-32]. This review will therefore emphasize the experimental aspects: the role of NE cells in androgen insensitivity, tumor growth and progression. Nevertheless, some clinical data will be provided to better understand the concept and the questions that emerge from it.

\section{Neuroendocrine cells in the normal prostate}

In normal prostatic epithelium, NE cells are found among the well-known prostate specific antigen (PSA) producing exocrine cells and basal cells (Fig. 1) [2]. Such cells were described for the first time by Pretl in 1944 as the argentaffin basal cells [84]. In this study the argentaffin cells were identified by silver staining procedures as well as autofluorescence techniques [84]. Prostatic NE cells are located in the glandular and ductal epithelium and they form only a small part of the epithelial cell compartment. They clearly belong to the "dispersed epithelial endocrine cell" type [39]. NE cells are found throughout the whole prostate although they are more abundant in the periurethral and ductal regions [23]. In the guinea pig prostate the num- 

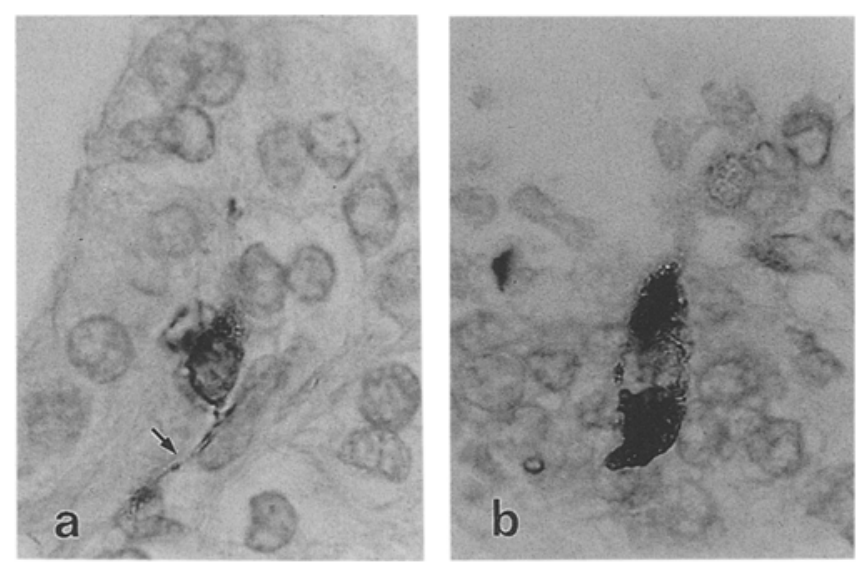

Fig. 1a, b Prostatic neuroendocrine cells. a Closed-type neuroendocrine cell with cytoplasmic process (arrow). b Open-type neuroendocrine cell. Chromogranin A staining with immunoperoxidase technique, nuclear counterstaining with hematoxylin, $\times 900$

ber of NE cells increases with age [38], a phenomenon which has not been described for humans [23]. NE cells in the glandular acini but not in the periurethral and ductal epithelium of the human prostate were found to disappear soon after birth and to reappear at puberty [23]. These findings suggest a direct or indirect effect of circulating androgens on the acinar NE cells but not on periurethral and ductal NE cells.

Morphologically, two types of prostatic NE cells can be recognized: a closed type separated by other cells from the lumen (Fig. 1a) and an open type reaching to the glandular lumen (Fig. 1b) [37]. The closed type often has dendritic cytoplasmic processes interdigitating between neighboring cells [37]. Prostatic NE cells are ultrastructurally characterized by so-called dense core granules or neurosecretory granules [36]. Based on the variations in the ultrastructural morphology of the granules a greater heterogeneity of $\mathrm{NE}$ cells has been suggested [36].

The heterogeneity of this cell type is also apparent from the variety of products (biogenic amines or peptide hormones) which they secrete. Chromogranin $\mathrm{A}$ and $\mathrm{B}$ ( $\mathrm{CgA}$ and $\mathrm{CgB}$ ), secretogranin II, neuron-specific enolase (NSE) and serotonin (5-HT) are found in most, if not all, prostatic NE cells $[3,8,37,90]$. A small number of these cells also contain calcitonin (CT) and related peptides such as calcitonin gene related peptide (CGRP) and katacalcin [27, $29,35,40,94]$. In addition, somatostatin (SMS) [27, 34], bombesin/gastrin-related peptide (GRP) [29], $\beta$-chain midportion of thyroid-stimulating hormone $[1,4]$, glycoprotein hormone $\alpha$-chain [41] and parathyroid hormone related protein have been found [50].

The chromogranins are acidic glycoproteins which are widely expressed in NE cells [112]. Various biologically active peptides can be released from the $\mathrm{CgA}$ and $\mathrm{CgB}$ molecules by enzymatic action $[68,112]$. A third chromogranin (chromogranin C) is now known as secretogranin II [48, 112]. Most of the immunohistochemical studies on NE differentiation have been performed with antibodies specific for CgA or 5-HT. NSE ( $\gamma$-enolase, a subtype of the glycolytic enzyme enolase) was thought to be an exclusive marker of endocrine and NE cells, but it has been shown that NSE is secreted by a large variety of other cell types [49].

The heterogeneous morphology of the neurosecretory granules and the diversity of secreted products suggest that these cells exert a number of distinct functions, which so far have been virtually unknown. In parallel with functions of NE cells in more extensively studied systems (i.e., lung, pancreas and adrenals), a role of these cells in growth and differentiation, and in maintenance of homeostasis has been suggested $[47,99,111]$. Some of the neuropeptides share growth factor activity (reviewed in $[25,92,105]$ ). Relatively high levels of CT, GRP/bombesin and SMS have been found in human semen $[45,88,98]$. Exposure to salmon-CT (sCT) decreased sperm motility in vitro [44]. Furthermore, sCT also increased the secretion of prostatic alkaline phosphatase by rat ventral prostate explants in a dose-dependent manner [61]. These studies indicate that prostatic NE cells might also have some exocrine functions.

According to Feyrter's original concept of the diffuse endocrine organ, all NE cells throughout the body were thought to originate from the neural crest [59]. However, nowadays a local origin of the NE cells in most tissues is suggested and has been proven, for example, in colorectal epithelium [59]. A multidirectional differentiation has been postulated for normal tissues as well as for tumors arising in these tissues (reviewed by DeLellis [28]). In a recent immunohistochemical study, some prostatic NE cells expressed basal cell specific cytokeratins and a few NE cells in hyperplastic glands displayed immunoreactivity for PSA [8, 17]. These observations suggest a common differentiation pathway of prostatic secretory, NE and basal cells and it is now generally accepted that prostatic NE cells indeed originate from the prostate. It may be hypothesized that the basal cell layer contains the prostatic stem cells and that these cells give rise to both the exocrine and NE phenotypes of the glandular epithelium.

\section{Neuroendocrine cells in the hyperplastic prostate}

The presence of NE cells in hyperplastic prostatic tissue has been demonstrated using silver staining techniques $[10$, 57]. In one study, up to 16 out of 20 hyperplastic nodules displayed NE differentiation [10]. However, in another study it was found that hyperplastic nodules in general contained less argentaffin NE cells than the adjacent normal epithelium [57]. This was confirmed in a recent study using immunohistochemistry with a 5-HT antibody and chromatographic quantification of the 5-HT content of tissue homogenates [20]. On the other hand, Abrahamsson et al. [3] found more NE cells in hyperplastic prostatic tissue than in normal glands as defined by immunoreactivity for 5-HT, thyroid-stimulating hormone and CT. Aprikian et al. [8] found immunohistochemically defined NE cells in all investigated hyperplastic specimens, although their rela- 
tionship with the adjacent normal glands was not studied. Whether or not neuroendocrine cells play a role in the pathogenesis of benign prostatic hyperplasia is not clear at the moment. The study of Cockett et al. [20] gives some support to this idea since they found more NE cells in small hyperplastic nodules than in normal prostate or large hyperplastic nodules. This suggests that the growth of the more immature small hyperplastic nodules is stimulated by NE products. Alternatively, the presence of NE cells may simply reflect an enhanced proliferative activity of glandular epithelial cells in prostatic hyperplasia.

\section{Neuroendocrine cells in the neoplastic prostate}

NE cells can be identified in prostate cancers (Fig. 2), although the percentage of tumors with NE cells varies in the literature from about $10 \%$ to almost $100 \%$. This variation partially reflects the development of techniques used to identify NE cells. An extensive recently published study indicated that NE cells are present in about $60 \%$ of prostate cancers [8]. Two papers on the argentaffin cells in the hyperplastic and neoplastic prostate were published in the 1970 s $[10,57]$, but only recently have NE cells in prostate cancer gained increasing attention.

According to Di Sant'Agnese [31], the term NE differentiation in prostate cancer includes the pathological categories small cell prostate cancer (SCPC), prostatic carcinoid, adenocarcinoma with scattered NE cells and mixed tumors of these three types. A relatively small proportion of prostatic adenocarcinomas with NE differentiation contain NE cells with large eosinophilic granules. This phenomenon was termed Paneth cell like change [6]. Very recently it has been suggested that these cells be renamed "NE cells with large eosinophilic granules" $[6,33]$. Obviously, the tumors with this type of NE cell also fit in the category of prostate cancer with NE differentiation. From a clinical point of view, prostate cancer with evidence of eutopic or ectopic production of neuroendocrine hormones and/or markers and prostatic malignancies associated with paraneoplastic syndromes linked to NE differentiation should also be included in the definition [31].

Undifferentiated small cell cancers, also referred to as NE carcinomas, occur in various organs, but most often in the lungs. SCPC is a relatively rare disease, accounting for $\pm 1-5 \%$ of all prostate cancers, and has been described in a few larger studies $[76,86,91,104]$. It is a highly malignant disease with a mean survival time of $7-17$ months [76, 104]. In about half of the patients the small cell component is preceded by a common adenocarcinoma, suggesting that at least in a number of patients the small cell carcinoma arises in a common adenocarcinoma. In line with this suggestion, a number of mixed tumors have been found $[76,104]$. Not all SCPC showed NE differentiation, however [86]. Prostatic carcinoid is a very rare entity. Only some case reports have been published as yet $[7,43,67$, $101,109,110]$. Carcinoids occur especially in the digestive system (appendix) and they are in general relatively

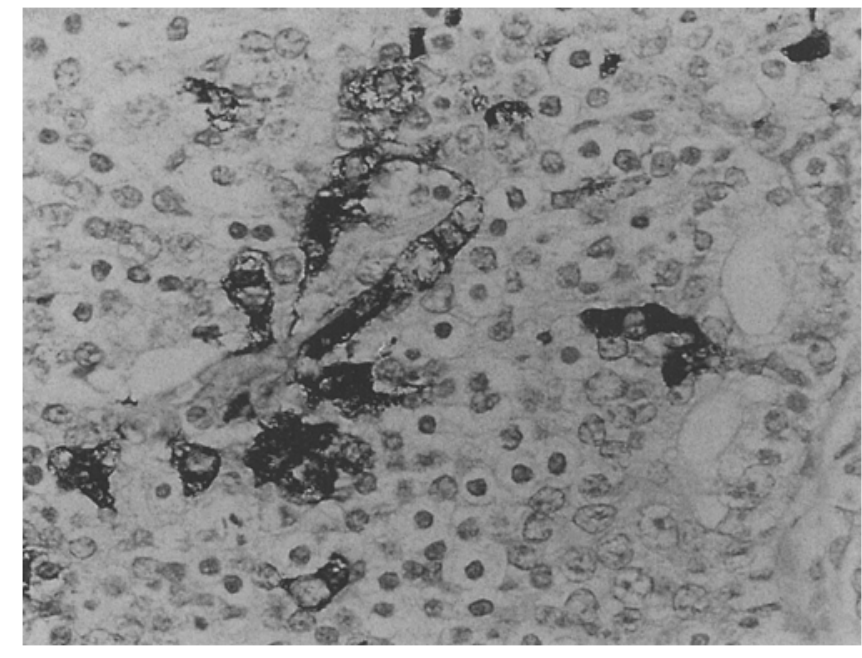

Fig. 2 Prostatic adenocarcinoma with neuroendocrine cells. Chromogranin A staining with immunoperoxidase technique, nuclear counterstaining with hematoxylin, $\times 175$

benign [46]. It appears that prostatic carcinoid tumors behave more aggressively $[31,101]$, although detailed studies with follow-up data are lacking. Mixed carcinoid-adenocarcinoma tumors have been found and it has been suggested that carcinoid formation in a hormonally treated adenocarcinoma might be a selective effect of the treatment [101].

The most common pattern of NE differentiation in prostate cancer is a prostatic adenocarcinoma with scattered NE cells. The number of NE cells within an adenocarcinoma varies from patient to patient and their presence may have prognostic significance $[5,18,21,22,26]$. Some authors found a relationship between the tumor grade and the number of NE cells $[4,5]$, but others did not [8]. NE cells were identified in about $50 \%$ of lymph node and bone metastases of prostatic adenocarcinomas [9]. This proves that NE cells are an intrinsic component of the adenocarcinoma and are not derived from preexistent benign glands. The presence of NE cells in metastatic lesions had no prognostic value [9]. Serum levels of $\mathrm{CgA}$ showed a $60 \%$ correlation with the immunohistochemical staining of this protein, and the presence of metastatic disease was better predicted by serum $\mathrm{CgA}$ levels than by tissue immunoreactivity [70]. The possible correlation between tumor grade and the number of NE cells in a tumor may well account for part or all of the reported prognostic value of NE differentiation, which would indicate that the number of NE cells just reflects the level of dedifferentiation of a tumor. This possibility can be investigated with long-term clinical follow-up studies using multiple regression analysis.

\section{Secretion products and hormone sensitivity}

NE cells in prostatic tumors are most often recognized by their immunoreactivity for NE markers (CgA, NSE) or eu- 


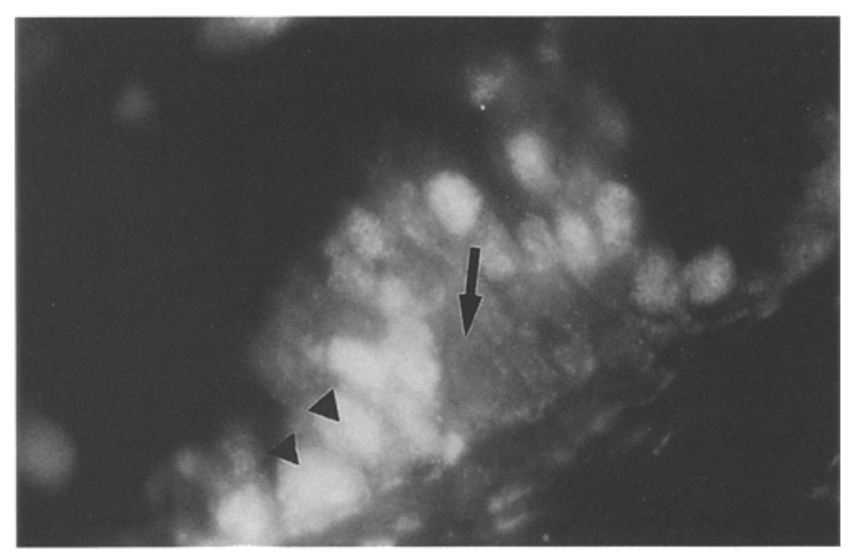

Fig. 3 Androgen receptor $(A R)$ and chromogranin $\mathrm{A}(C g A)$ double labeling in a benign prostatic gland. Nuclear AR staining with immunofluorescence technique (FITC, originally green). CgA staining with alkaline phosphatase technique (originally red fluorescence signal). Most epithelial cells display a strong AR positivity (arrowheads). The triangular-shaped closed-type neuroendocrine cell ( $a r-$ row) is AR negative. $\times 250$ (Reproduced from $[60]$ with kind permission)

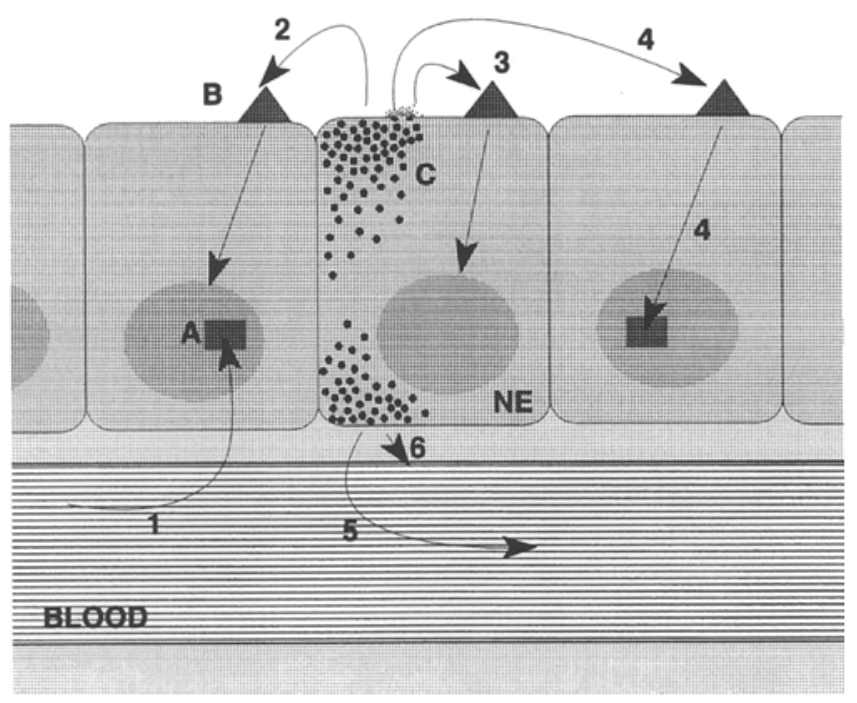

Fig. 4 Influence of a neuroendocrine $(N E)$ cell on neighboring non$\mathrm{NE}$ cells (working hypothesis). $I$ actions of androgens mediated by the nuclear androgen receptor $(A), 2,3,4$ action of neuropeptides released from the neurosecretory vesicles $(C)$ of the NE cell, 2 paracrine stimulation of neighboring non-NE cell by activation of neuropeptide receptor, 3 autocrine stimulation, 4 ligand-independent activation of androgen receptor in non-NE cell, 5 systemic action of neuropeptides secreted into the blood (paraneoplastic symptoms), 6 stromal effects of neuropeptides

topic bioactive peptides (5-HT, CT, SMS and others). In addition to the eutopic peptide products, a number of ectopic peptides have been found, for example, adrenocorticotropic hormone (ACTH), leu-enkephalin and $\beta$-endorphin [4]. Expression of these factors, especially ACTH, might cause a paraneoplastic syndrome as occasionally found in prostate cancer patients (reviewed by Matzkin and Braf [65]). In high-grade tumors with marked NE differen- tiation, $\mathrm{CgB}$ replaced $\mathrm{CgA}$ expression by $\mathrm{NE}$ cells [90]. This implies that in immunohistochemical studies $\mathrm{CgA}$ as well as $\mathrm{CgB}$ immunoreactivity has to be assessed.

Kadmon et al. demonstrated elevated $\mathrm{CgA}$ serum levels in 12 out of 25 patients with metastatic, hormone-insensitive prostate cancer [55]. Moreover, in 4 of these 12 patients PSA levels were in the normal range. Serum levels of NSE were found to be increased more often in patients with hormone refractory tumors $(10 / 46)$ than in patients with hormone-sensitive tumors (2/89) [103]. Abrahamsson et al. studied NE differentiation in repeated biopsy specimens of patients treated with hormonal therapy or with radiotherapy [5]. They found mostly an increasing number of NE cells during follow-up paralleled by dedifferentiation and hormonal escape (i.e., progression) of the tumor. These results raise the question whether NE cells in prostate tumors are androgen sensitive or not. NE cells in benign and malignant prostatic tissues contained rarely, if at all, androgen receptor immunoreactivity (Fig. 3) [16, 601 . In another study, using a different antibody for the androgen receptor, prostatic NE cells generally expressed the androgen receptor [71]. Very recently the authors of the latter study confirmed the findings of the former two studies [33], leading to the conclusion that NE cells in the normal or neoplastic prostate do not contain the androgen receptor. It has been shown that the androgen receptor content of a prostatic tumor does not predict androgen (in)sensitivity $[87,107]$. It is, however, unlikely that androgen receptor negative tumor cells will respond to androgen withdrawal. Therefore, NE cells in prostate cancer most probably form a primarily androgen-insensitive tumor cell population.

\section{Growth modulation by neoplastic neuroendocrine cells}

A number of peptides produced by NE prostatic tumor cells (5-HT, GRP/bombesin, CT, SMS) exhibit growth factor activities mediated by a membrane receptor. This may represent a way of paracrine or autocrine growth modulation $[25,92,111]$. Most of the prostatic adenocarcinoma cells surrounding NE cells contain the androgen receptor, even in androgen refractory carcinomas $[16,60]$. It was found in COS cells transfected with steroid hormone receptors that dopamine activated several steroid hormone receptors (progesterone, estrogen, vitamin D and thyroid hormone $\beta$-receptors) in a ligand-independent fashion [83]. In this way NE tumor cells might influence the growth of neighboring non-NE tumor cells by androgen-independent activation of the androgen receptor in a paracrine manner. It is, however, not known yet if the androgen receptor can be activated similarly by neuropeptides and, therefore, this should be studied first. It should be stressed that neuropeptides may enhance or inhibit growth, depending on the specific nature of the neuropeptide and properties of the target cell. Bonkhoff et al. found in an immunohistochemical study that proliferating cells in normal, hyperplastic and cancerous prostatic tissues were usually, but not necessar- 
ily, located in the proximity of clusters of NE cells [15]. This supports the concept of paracrine growth regulation by prostatic NE cells.

The following hypothesis can be postulated: NE cells in a prostatic adenocarcinoma form a subset of primarily androgen-independent tumor cells which modulate the growth of neighboring non-NE tumor cells by the secretion of neuropeptides in a paracrine manner (Fig. 4). Granted this hypothesis, one would expect that following androgen withdrawal the proportion of NE cells would increase. Abrahamsson et al. described in a group of 24 hormonally treated patients that the number of NE cells increased in time, although this was paralleled by dedifferentiation of the tumors (see above) [5]. Aprikian et al. were not able to confirm the observed increase in NE differentiation following short- or long-term hormonal therapy, however [8]. Larger follow-up studies on long-term androgen-depleted tumors with assessments of absolute and relative numbers of NE cells should confirm the occurrence of this phenomenon. Even if the NE cell population does not increase following androgen withdrawal, the secreted neuropeptides may still stimulate the surrounding non-NE cells by acting as "androgen substitutes." The secreted neuropeptides may also have effects on stromal cells (stromal-epithelial interactions), a possibility which has not been studied as yet.

\section{Specific neuropeptides}

\section{Serotonin}

Serotonin (5-HT) is well known as a neurotransmitter and vasoactive peptide and some recent reports indicate that 5-HT also has growth factor activity $[56,93]$. 5-HT stimulated DNA synthesis in hamster fibroblasts proved to be mediated by activation of the $5-\mathrm{HT}_{1 \mathrm{~b}}$ receptor [93]. This receptor is only expressed in rodents. Further experiments indicated that in humans 5-HT mediates the proliferation of smooth muscle cells mediated through activation of the $5-\mathrm{HT}_{1 \mathrm{~d}}$ receptor [56]. 5-HT might influence tumor growth indirectly by changing the local blood flow in a tumor due to its vasoactive action. It is very likely that 5 -HT plays a role in the prostate since it is expressed by most if not all prostatic NE cells $[3,8,37]$. Unfortunately, it is as yet not known if human prostatic tumor cells contain 5-HT receptors and, if so, which subtypes. If prostatic tumor cells contain 5-HT receptors, 5-HT may also exert its effect by ligand-independent activation of the androgen receptor [83].

\section{Bombesin/gastrin-related peptide}

Gastrin-related peptide (GRP) is the mammalian analogue of the amphibian peptide bombesin [102]. GRP stimulated the growth of cultured normal bronchial epithelial cells in a dose-dependent manner [111]. In vitro studies with cultured pulmonary NE cells demonstrated that treatment with
GRP increased the number of NE cells and stimulated their 5-HT expression while treatment with 5-HT did not [99]. It has also been shown that GRP stimulated growth of small cell lung cancer cells [24]. This effect could be blocked in vivo by an antibody against GRP and in vitro by GRP analogues, which prevent binding of GRP to its receptor [24, 64]. In vitro studies with the androgen-independent prostatic cancer cell line PC-3 similarly showed a growth stimulatory action of GRP which could be blocked by an antiGRP antibody [14]. Saturable GRP-binding sites were demonstrated on PC-3 cells, but no immunoreactivity for GRP was demonstrated in these cells, excluding an autocrine action of GRP [14]. The GRP antagonist RC-3095 was able to inhibit the growth of the androgen-dependent human xenograft PC-82, the Dunning R-3327H rat prostate tumor and the androgen-independent DU-145 and PC-3 prostatic in vitro cell lines [66, 80-82]. Saturable GRP-binding sites were demonstrated on cells of all these models. Altogether, evidence exists that GRP has a potential role in the growth of (neoplastic) prostatic tissue.

\section{Calcitonin}

The human (hCT) and salmon (sCT) subtypes of CT can be demonstrated in a subset of normal and neoplastic prostatic cells $[4,8,27,29,35,40,94,96]$. In conditioned medium of cultures of prostate cancer cells, immunoreactive CT was found in a concentration fourfold higher than in cultures of BPH cells [94]. In vivo administration of sCT to rats induced ornithine decarboxylase (a key enzyme associated with cell cycle progression and growth) in a number of organs [73]. It should be realized that CT also inhibits the pituitary secretion of luteinizing hormone, which is an important hormone in the mediation of androgen secretion [62]. In addition, the secretion of prolactin, which influences the action of androgens on the prostate, was also found to be decreased by CT [12]. Therefore, a pituitarymediated growth-inhibiting effect of CT on prostatic cancer growth is also expected. The direct growth-modulating effects of CT have been studied in a few tumor systems. T-47D breast cancer cells contained high-affinity receptors for CT, and in vitro growth of these cells was dose dependently inhibited by CT $[51,75]$. Comparable results were found in cells of the human gastric carcinoma cell line KATO III [72]. Following CT administration, intracellular cAMP levels increased $[51,72,75]$. This increase was also found in four out of six renal adenocarcinoma cell lines and only these four cell lines were growth inhibited by CT administration [58]. In a panel of 13 small cell lung cancer cell lines, 2 contained CT and only 1 was able to bind CT while no growth effect upon CT administration was found [11]. It has recently been shown that SCT dose dependently increased the cAMP concentration and the DNA synthesis in cells of the in vitro human prostatic cancer cell line LNCaP [95]. The growth stimulatory effect of CT in $\mathrm{LNCaP}$ cells is at variance with the results from other nonprostatic tumor model systems $[51,58,72,75]$. Therefore, the effects of CT have to be confirmed in additional stud- 
ies using other prostatic tumor models including in vivo models because CT also has systemic effects which may influence prostatic tumor growth.

\section{Somatostatin}

Abrahamsson et al. [4] found somatostatin (SMS) immunoreactivity in 12 out of 40 prostatic adenocarcinomas, a result that has not been confirmed by Aprikian et al. [8]. SMS receptors were found neither in 17 prostatic carcinomas nor in $2 \mathrm{BPH}$ specimens [85]. On the other hand, binding sites for several SMS analogs were demonstrated in normal and neoplastic prostatic tissues [100]. A number of experimental studies concerning the growth-modulating effects of SMS in prostate cancer have been published. Several SMS analogs (sandostatin, somatuline, RC-160, RC121) decreased without exception the growth of prostatic tumor models in vivo (Dunning R-3327 and R-3327H, PC$82, \mathrm{DU}-145, \mathrm{PC}-3)$ and in vitro (LNCaP) $[13,19,54,66$, $69,80,82,89,97,113]$. In the Dunning R-3327H rat tumor the SMS effect potentiated the castration-induced growth inhibition even when the tumors became androgen independent [13]; however, this was not confirmed by others [97]. In experiments with heterotransplants of the androgen-independent PC-3 cell line, SMS was able to inhibit growth only if the tumors were small $\left(10 \mathrm{~mm}^{3}\right)$ [82]. Combination treatment of tumor models with an SMS analog and luteinizing hormone-releasing hormone (LH-RH) analog (D-TRP $\left.{ }^{6} \mathrm{LH}-\mathrm{RH}\right)$ resulted in a stronger growth inhibition than treatment with only one of the components $[54,66,89]$. SMS-binding sites were demonstrated on cells of the PC-82 [66], Du-145 [80], PC-3 [82] and Dunning R$3327 \mathrm{H}$ [54] models. SMS and prolactin-binding sites were found to be downregulated in Dunning R-3327H tumors treated with analogs of SMS and LH-RH [54]. As noted above, prolactin may have a stimulating effect on prostate cancer, and the downregulation of the prolactin receptor by SMS might partially explain the growth-inhibiting effects of SMS. All these results strongly suggest a direct growthinhibiting effect of SMS (analogs) in prostate cancer.

The effects of some of the neuropeptides on prostate cancer growth have been investigated quite extensively. The relationship with androgen levels and androgen receptor activity, the action of a combination of neuropeptides and the mechanisms of action are poorly understood at the moment. Furthermore, it is not clear whether the amounts of neuropeptides secreted by the NE cells are sufficient for biological activity on neighboring cells. For some of the neuropeptides, the presence of the corresponding receptor is not clear. Possibly other, as yet unknown, factors produced by prostatic NE cells may be even more important.

\section{Neuroendocrine differentiation in prostatic tumor models}

To enhance our knowledge of NE differentiation in prostate cancer, experimental models with NE cells are urgently needed. A heterotransplantable model of a small cell prostatic carcinoma has been established [52, 53, 108]. An SCPC is biologically different from an adenocarcinoma and, therefore, this model is probably not useful for the study of the paracrine role of NE cells in prostatic adenocarcinoma. None of the available prostatic tumor models contains NE cells as defined by immunoreactivity for $\mathrm{CgA}$, 5-HT, CT, SMS, NSE and thyroid-stimulating hormone, although two heterotransplantable human tumor models which were recently established in this laboratory contain CgA-positive cells (unpublished observation).

Possibly, NE differentiation can be induced in non-NE prostatic tumor models. Transfection of $\mathrm{v}-$ ras $^{\mathrm{H}}$ into DMS53 small cell lung cancer cell line cells resulted in a cell line with increased NE features [63]. Transfection of both c-raf-1 and c-myc oncogenes into SV-40-immortalized bronchial epithelial cells resulted in the generation of heterotransplantable large cell carcinoma cell lines with an NE phenotype $[78,79]$. These studies indicate that NE differentiation can be induced and that it is associated with the expression of certain (proto-) oncogenes. Future experiments have to show if a similar approach can be applied to prostate cancer.

\section{Conclusion}

Knowledge about the function of NE cells in the human prostate and prostate cancer is limited. Evidence is, however, accumulating that NE cells and tumors with NE cells are related to the androgen-independent and poorly differentiated types of prostate cancer. However, at the moment it cannot be excluded that NE differentiation is only an epiphenomenon associated with dedifferentiation of a tumor. There is evidence that the secretion products of prostatic NE cells affect prostate cancer growth and possibly also affect tumor differentiation. Research directed towards identifying the role of NE cells in prostate cancer is likely to contribute to the understanding of the transition of androgen-dependent to androgen-independent prostate cancer.

\section{References}

1. Abrahamsson PA, Lilja $\mathbf{H}$ (1989) Partial characterization of a thyroid-stimulating hormone-like peptide in neuroendocrine cells of the human prostate gland. Prostate 14:71

2. Abrahamsson PA, Di Sant'Agnese PA (1993) Neuroendocrine cells in the human prostate gland. J Androl 5:307

3. Abrahamsson PA, Wadström LB, Alumets J, Falkmer S, Grimelius L (1986) Peptide-hormone- and serotonin-immunoreactive cells in normal and hyperplastic prostate glands. Pathol Res Pract 181:675

4. Abrahamsson PA, Wadström LB, Alumets J, Falkmer S, Grimelius L (1987) Peptide-hormone- and serotonin-immunoreactive tumour cells in carcinoma of the prostate. Pathol Res Pract $182: 298$

5. Abrahamsson PA, Falkmer S, Falt K, Grimelius L (1989) The course of neuroendocrine differentiation in prostatic carcino- 
mas. An immunohistochemical study testing chromogranin A as an "endocrine marker". Pathol Res Pract 185:373

6. Adlakha H, Bostwick DG (1994) Paneth cell-like change in prostatic adenocarcinoma represents neuroendocrine differentiation: Report of 30 cases. Hum Pathol 25:135

7. Almagro UA, Minh Tieu T, Remeniuk E, Kueck B, Strumpf K (1986) Argyrophilic, ,carcinoid-like " prostatic carcinoma. Arch Pathol Lab Med 1 10:916

8. Aprikian AG, Cordon Cardo C, Fair WR, Reuter VE (1993) Characterization of neuroendocrine differentiation in human benign prostate and prostatic adenocarcinoma. Cancer 71:3952

9. Aprikian AG, Cordon Cardo C, Fair WR, Zhang ZF, Bazinett M, Hamdy SM, Reuter VE (1994) Neuroendocrine differentiation in metastatic prostatic adenocarcinoma. J Urol 151:914

10. Azzopardi JG, Evans DJ (1971) Argentaffin cells in prostatic carcinoma: Differentiation from lipofuscin and melanin in prostatic epithelium. J Pathol 104:247

11. Bepler G, Rotsch M, Jaques G, Haeder M, Heymanns J, Hartogh $G$, Kiefer P, Havemann K (1988) Peptides and growth factors in small cell lung cancer: production, binding sites, and growth effects. J Cancer Res Clin Oncol 114:235

12. Bloom SR, Ghatei MA, Christofides ND (1979) Bombesin infusion in man, pharmacokinetics and effect on gastrointestinal and pancreatic hormonal peptides. I Endocrinol 83:51

13. Bogden AE, Taylor JE, Moreau JP, Coy DH (1990) Treatment of R-3327 prostate tumors with a somatostatin analogue (Somatuline) as adjuvant therapy following surgical castration. Cancer Res 50:2646

14. Bologna M, Festuccia C, Muzi P, Biordi L, Ciomei M (1989) Bombesin stimulates growth of human prostatic cancer cells in vitro. Cancer 63:1714

15. Bonkhoff H, Wernert N, Dhom G, Remberger K (1991) Relation of endocrine-paracrine cells to cell proliferation in normal, hyperplastic, and neoplastic human prostate. Prostate 19:91

16. Bonkhoff H, Stein U, Remberger K (1993) Androgen receptor status in endocrine-paracrine cell types of the normal, hyperplastic and neoplastic prostate. Virchows Archiv [A] Pathol Anat Histopathol 423:291

17. Bonkhoff H, Stein U, Remberger K (1994) Multidirectional differentiation in the normal, hyperplastic, and neoplastic human prostate: Simultaneous demonstration of cell-specific epithelial markers. Hum Pathol 25:42

18. Bono AV, Pozzi E (1985) Endocrine-paracrine cells in prostatic carcinoma and clinical course of the disease. Eur Urol 11: 195

19. Brevini TAL, Bianchi R, Motta M (1993) Direct inhibitory effect of somatostatin on the growth of the human prostatic cancer cell line LNCaP: Possible mechanism of action. J Clin Endocrinol Metab 77:626

20. Cockett TK, Di Sant'Agnese PA, Gopinath P, Schoen SR, Abrahamsson PA (1993) Relationship of neuroendocrine cells of prostate and serotonin to benign prostatic byperplasia. Urology $42: 512$

21. Cohen RJ, Glezerson G, Haffejee Z, Afrika D (1990) Prostatic carcinoma: histological and immunohistological factors affecting prognosis. Br J Urol 66:405

22. Cohen RJ, Glezerson G, Haffejee Z (1991) Neuro-endocrine cells - a new prognostic parameter in prostate cancer. Br J Urol $68: 258$

23. Cohen RJ, Glezerson G, Taylor LF, Grundle HAJ, Naude JH (1993) The neuroendocrine cell population of the human prostate gland. I Urol 150:365

24. Cuttitta F, Carney DN, Mulshine J, Moody TW, Fedorko J, Fischler A, Dinna JM (1985) Bombesin-like peptides can function as autocrine growth factors in human simall-cell lung cancers. Nature 316:823

25. Dalsgaard CJ, Hultgardh Nilsson A, Haegerstrand A, Nilsson J (1989) Neuropeptides as growth factors. Possible roles in human diseases. Regul Pept 25:1

26. Dauge MC, Delmas V (1987) APUD type endocrine tumour of the prostate. Incidence and prognosis in association with adenocarcinoma. Prog Clin Biol Res 243A:529
27. Davis NS, Di Sant'Agnese PA, Ewing JF, Mooney RA (1989) The neuroendocrine prostate: characterization and quantitation of calcitonin in the human gland. J Urol 142:884

28. DeLellis RA, Tischler AS, Wolfe HJ (1984) Multidirectional differentiation in neuroendocrine neoplasms. J Histochem Cytochem 32:899

29. Di Sant'Agnese PA (1986) Calcitonin-like immunoreactive and bombesin-like immunoreactive endocrine-paracrine cells of the human prostate. Arch Pathol Lab Med 11:412

30. Di Sant'Agnese PA (1988) Neuroendocrine differentiation and prostatic carcinoma. The concept, comes of age". Arch Pathol Lab Med 112:1097

31. Di Sant Agnese PA (1992) Neuroendocrine differentiation in carcinoma of the prostate - diagnostic, prognostic, and therapeutic implications. Cancer 70:254

32. Di Sant'Agnese PA (1992) Neuroendocrine differentiation in human prostatic carcinoma. Hum Pathol 23:287

33. Di Sant'Agnese PA (1994) Neuroendocrine differentiation in prostatic adenocarcinoma does not represent true Paneth cell differentiation (editorial). Hum Pathol 25:115

34. Di Sant'Agnese PA, De Mesy Jensen KL (1984) Somatostatin and/or somatostatin-like immunoreactive endocrine-paracrine cells in the human prostate gland. Arch Pathol Lab Med 108:693

35. Di Sant'Agnese PA, De Mesy Jensen KL, Ackroyd RK (1989) Calcitonin, katacalcin, and calcitonin gene-related peptide in the human prostate. An immunocytochemical and immunoelectron microscopic study. Arch Pathol Lab Med 113:790

36. Di Sant'Agnese PA, De Mesy Jensen KL (1984) Endocrine-paracrine cells of the prostate and prostatic urethra: An ultrastructural study. Hum Pathol 15:1034

37. Di Sant'Agnese PA, De Mesy Jensen KL, Chuirukian CJ, Agarwal MM (1985) Human prostatic endocrine-paracrine (APUD) cells. Arch Pathol Lab Med 109:607

38. Di Sant'Agnese PA, Davis NS, Chen M, De Mesy Jensen KL (1987) Age-related changes in the neuroendocrine (endocrine paracrine) cell population and the serotonin content of the guinea pig prostate. Lab Invest 57:729

39. Erlandson RA, Nesland JM (1.994) Tumors of the endocrine/neuroendocrine system: an overview. Ultrastruct Pathol $18: 149$

40. Fetissof F, Bertrand G, Guilloteau D, Dubois MP, Lanson Y, Arbeille B (1986) Calcitonin immunoreactive cells in prostate gland and cloacal derived tissues. Virchows Arch A Pathol Anat 409:523

41. Fetissof F, Arbeille B, Guilloteau D, Lanson Y (1987) Glycoprotein hormone alpha-chain-immunoreactive endocrine cells in prostate and cloacal-derived tissues. Arch Pathol Lab Med 111:836

42. Feyrter F (1938) Uber diffuse endocrine epitheliale Organe Barth J, Leipzig

43. Ghali VS, Garcia RL (1984) Prostatic adenocarcinoma with carcinoidal features producing adrenocorticotropic syndrome: Immunohistochemical study and review of the literature. Cancer $54: 1043$

44. Gnessi L, Silvestroni L, Fabbri A, Moretti C, Panerai AE, Bonifacio V, Fraioli F (1984) Salmon calcitonin inhibits human sperm motility in vitro. Biochem Biophys Res Commun $125: 199$

45. Gnessi L, Ulisse S, Fabbri A, Jannini EA, Bonifacio V, Moretti C, Spera G, Isidori A (1989) Isolation of a human seminal plasma peptide with bombesin-like activity. Fertil Steril 51:1034

46. Godwin II JD (1975) Carcinoid tumors: an analysis of 2837 cases. Cancer $36: 560$

47. Grube D (1986) The endocrine cells of the digestive system amines, peptides, and modes of action. Anat Embryol 175 : 151

48. Hagn C, Schmid KW, Fischer Colbrie R, Winkler H (1986) Chromogranin $\mathrm{A}, \mathrm{B}$ and $\mathrm{C}$ in human adrenal medulla and en docrine tissues. Lab Invest 55:405

49. Haimoto H, Koshikawa T, Nagura H, Kato K (1985) Immunohistochemical localization of $\gamma$-enolase in normal human tissues 
other than nervous and neuroendocrine tissues. Lab Invest $52: 257$

50. Iwamura M, Wu G, Abrahamsson PA, Di Sant Agnese PA, Cockett ATK, Deftos LJ (1994) Parathyroid hormone-related protein is expressed by prostatic neuroendocrine cells. Urology 43:667

51. Iwasaki Y, Iwasaki J, Freake HC (1983) Growth inhibition of human breast cancer cells induced by calcitonin. Biochem $\mathrm{Bi}-$ ophys Res Comm 110:235

52. Jelbart ME, Russell PJ, Fullerton M, Russell P, Funder J, Raghavan D (1988) Ectopic hormone production by a prostatic small cell carcinoma xenograft line. Mol Cell Endocrinol 55:167

53. Jelbart ME, Russell PJ, Russell P, Wass J, Fullerton M, Wills EJ, Raghavan D (1989) Site-specific growth of the prostate xenograft line UCRU-PR-2. Prostate 14:163

54. Kadar T, Redding TW, Ben David M, Schally AV (1988) Receptors for prolactin, somatostatin, and luteinizing hormone-releasing hormone in experimental prostate cancer after treatment with analogs of luteinizing hormone-releasing hormone and somatostatin. Proc Natl Acad Sci USA 85:890

55. Kadmon D, Thompson TC, Lynch GR, Scardino PT (1991) Elevated plasma chromogranin-A concentrations in prostatic carcinoma. J Urol 146:358

56. Kavanaugh WM, Williams LT, Ives HE, Coughlin SR (1988) Serotonin-induced deoxyribonucleic acid synthesis in vascular smooth muscle cells involves a novel, pertussis toxin-sensitive pathway. Mol Endocrinol 2:599

57. Kazzaz BA (1974) Argentaffin and argyrophil cells in the prostate. J Pathol 112:189

58. Kinoshita Y, Fukase M, Takenaka M, Nakada M, Miyauchi A, Fujita $T$ (1985) Calcitonin stimulation of cyclic adenosine $3^{\prime}: 5^{\prime}$ monophosphate production with growth inhibition in human renal adenocarcinoma cell lines. Cancer Res 45:4890

59. Kirkland SC (1988) Clonal origin of columnar, mucous, and endocrine cell lineages in human colorectal epithelium. Cancer 61:1359

60. Krijnen JLM, Janssen PJA, Ruizeveld de Winter JA, Van Krimpen H, Schröder FH, Van der Kwast TH (1993) Do neuroendocrine cells in human prostate cancer express androgen receptor? Histochemistry 100:393

61. Latif A, Nakhla A (1994) Calcitonin releases acid phosphatases from rat ventral prostate explants. Life Sci 54:561

62. Leicht E, Biro G, Weinges KS (1974) Inhibition of releasinghormone-induced secretion of TSH and LH by calcitonin. Horm Metab Res 6:410

63. Mabry M, Nakagawa T, Baylin S, Pettengill O, Sorenson G, Nelkin B (1989) Insertion of the v-Ha-ras oncogene induces differentiation of calcitonin-producing human small cell lung cancer. J Clin Invest 84:194

64. Mahmoud S, Staley J, Taylor J, Bogden A, Moreau JP, Coy D, Avis I, Cuttitta F, Mulshine JL, Moody TW (1991) [Psi 13, 14] bombesin analogues inhibit growth of small cell lung cancer in vitro and in vivo. Cancer Res 51:1798

65. Matzkin H, Braf Z (1987) Paraneoplastic syndromes associated with prostatic carcinoma. J Urol 138:1129

66. Milovanovic SR, Radulovic S, Groot K, Schally AV (1992) Inhibition of growth of PC- 82 human prostate cancer line xenografts in nude mice by bombesin antagonist RC-3095 or combination of agonist [D-Trp6]-luteinizing hormone-releasing hormone and somatostatin analog RC-160. Prostate 20:269

67. Montasser AY, Ong MG, Mehta VT (1979) Carcinoid tumor of the prostate associated with adenocarcinoma. Cancer 44:307

68. Mouland AJ, Bevan S, White JH, Hendy GN (1994) Human chromogranin A gene: molecular cloning, structural analysis, and neuroendocrine cell-specific expression. J Biol Chem 269:6918

69. Murphy WA, Lance VA, Moreau S, Moreau JP, Coy DH (1987) Inhibition of rat prostate tumor growth by an octapeptide ana$\log$ of somatostatin. Life Sci 40:2515

70. Nakada S, Abrahamsson PA, Di Sant'Agnese PA, Casamento J, Cockett ATK (1993) Correlation between serum and tissue studies of chromogranin $\mathrm{A}$ as a neuroendocrine marker in patients with carcinoma of the prostate. J Urol 149 [Suppl]:480
71. Nakada SY, Di Sant'Agnese PA, Moynes RA, Hiipakka RA, Liao S, Cockett AT, Abrahamsson PA (1993) The androgen receptor status of neuroendocrine cells in human benign and malignant prostatic tissue. Cancer Res 53:1967

72. Nakamura A, Yamatani T, Arima N, Yamashita Y, Fujita T, Chiba T (1992) Calcitonin inhibits the growth of human gastric carcinoma cell line KATO III. Regul Pept 37:183

73. Nakhla AM (1987) Calcitonin induces ornithine decarboxylase in various rat tissues. Mol Cell Endocrinol 52:263

74. National Cancer Institute Prostate Cancer Working Group (1991) National Cancer Institute round table on prostate cancer: future research directions. Cancer Res 51:2498

75. Ng KW, Livesey SA, Larkins RG, Martin TJ (1983) Calcitonin effects on growth and on selective activation of type II isoenzyme of cyclic adenosine $3^{\prime}: 5^{\prime}$-monophosphatase-dependent protein kinase in $\mathrm{T} 47 \mathrm{D}$ human breast cancer cells. Cancer Res 43:794

76. Oesterling JE, Hauzeur CG, Farrow GM (1992) Small cell anaplastic carcinoma of the prostate: a clinical, pathological and immunological study of 27 patients. J Urol 147:804

77. Pearse AGE (1969) The cytochemistry and ultrastructure of polypeptide hormone-producing cells of the APUD series and the embryologic, physiologic and pathologic implications of the concept. J Histochem Cytochem 17:303

78. Pfeiffer AMA, Mark III GE, Malan Shelby L, Graziano S, Amstad P, Harris CC (1989) Cooperation of c-raf-1 and c-myc protooncogenes in the neoplastic transformation of simian virus 40 large tumor antigen-immortalized human bronchial epithelial cells. Proc Natl Acad Sci USA 86:10075

79. Pfeiffer AMA, Jones RT, Bowden PE, Mann D, Spillare E, Klein Szanto AJP, Trump BF, Harris CC (1991) Human bronchial epithelial cells transformed by the c-raf- 1 and c-myc protooncogenes induce multidifferentiated carcinomas in nude mice: $A$ model for lung cancer carcinogenesis. Cancer Res 51:3793

80. Pinski J, Halmos G, Schally AV (1993) Somatostatin analog RC-160 and bombesin/gastrin-releasing peptide antagonist RC3095 inhibit the growth of androgen-independent DU-145 human prostate cancer in nude mice. Cancer Lett 71:189

81. Pinski J, Halmos G, Szepeshazi K, Schally AV (1993) Antagonists of bombesin/gastrin-releasing peptide as adjuncts to agonists of luteinizing hormone-releasing hormone in the treatment of experimental prostate cancer. Cancer 72:3263

82. Pinski J, Schally AV, Halmos G, Szepeshazi K (1993) Effect of somatostatin analog RC-160 and bombesin/gastrin releasing peptide antagonist RC-3095 on growth of PC-3 human prostate-cancer xenografts in nude mice. Int J Cancer 55:963

83. Power RF, Mani SK, Codina J, Conneely OM, O'Malley BW (1991) Dopaminergic and ligand-independent activation of steroid hormone receptors. Science 254:1636

84. Pretl K (1944) Zur Frage der Endokrinie der menschlichen Vorsteherdrüse. Virchows Arch [A] 312:392

85. Reubi JC, Werder RMK von, Torhorst J, Klijn JGM, Lamberts SWJ (1987) Somatostatin receptors in human endocrine tumors. Cancer Res 47:551

86. Ro JY, Tetu B, Ayala AG, Ordonez NG (1987) Small cell carcinoma of the prostate. II. Immunohistochemical and electron microscopic studies of 18 cases. Cancer 59:977

87. Ruizeveld de Winter JA, Janssen PJA, Sleddens HMEB, Verleun Mooijman MCT, Trapman J, Brinkman AO, Santerse AB, Schröder FH, Van der Kwast TH (1994) Androgen receptor status in localized and locally progressive hormone refractory human prostate cancer. Am J Pathol 144:735

88. Sasaki A, Yoshinaga K (1989) Immunoreactive somatostatin in male reproductive system in humans. J Clin Endocrinol Metab 68:996

89. Schally AV, Redding TW (1987) Somatostatin analogs as adjuncts to agonists of luteinizing hormone-releasing hormone in the treatment of experimental prostate cancer. Proc Natl Acad Sci USA 84:7275

90. Schmid KW, Helpap B, Totsch M, Kirchmair R, Dockhorn Dworniczak B, Bocker W, Fischer Colbrie R (1994) Immunohistochemical localization of chromogranins A and B and sec- 
retogranin II in normal, hyperplastic and neoplastic prostate. Histopathology 24:233

91. Schron DS, Gipson T, Mendelsohn G (1984) The histogenesis of sinall cell carcinoma of the prostate: An immunohistochemical study. Cancer 53:2478

92. Seuwen K, Pouyssegur J (1990) Serotonin as a growth factor. Biochem Pharmacol 39:985

93. Seuwen K, Magnaldo I, Pouyssegur J (1988) Serotonin stimulates DNA synthesis in fibroblasts acting through 5-HT1b receptors coupled to a Gi-protein. Nature 335:254

94. Shah GV, Noble MJ, Austenfeld M, Weigel J, Deftos LJ, Mebust WK (1992) Presence of calcitonin-like immunoreactivity (iCT) in human prostate gland: evidence for $\mathrm{iCT}$ secretion by cultured prostate cells. Prostate 21:87

95. Shah GV, Rayford W, Noble NJ, Austenfeld M, Weigel J, Vamos S, Mebust WK (1994) Calcitonin stimulates growth of human prostate cancer cells through receptor-mediated increase in cyclic adenosine $3^{\prime}: 5^{\prime}$-monophosphates and cytoplasmic $\mathrm{Ca}^{2+}$ transients. Endocrinology 134:596

96. Shulkes A, Fletcher DR, Rubinstein C, Ebeling PR, Martin TJ (1991) Production of calcitonin gene related peptide, calcitonin and PTH-related protein by a prostatic adenocarcinoma. Clin Endocrinol (Oxf) 34:387

97. Siegel RA, Tolcsvai L, Rudin M (1988) Partial inhibition of the growth of transplanted Dunning rat prostate tumors with the long-acting somatostatin analogue sandostatin (SMS 201-995). Cancer Res 48:4651

98. Sjoberg HE, Arver S, Bucht E (1980) High concentration of immunoreactive calcitonin of prostatic origin in human semen Acta Physiol Scand 110:101

99. Speirs V, Bienkowski E, Wong V, Cutz E (1993) Paracrine effects of bombesin/gastrin related peptide and other growth factors on pulmonary neuroendocrine cells in vitro. Anat Rec 236:53

100. Srkalovic G, Cai RZ, Schally RV (1990) Evaluation of receptors for somatostatin in various tumors using different analogs. J Clin Endocrinol Metab 70:661

101. Stratton M, Evans DJ, Lampert IA (1986) Prostatic adenocarcinoma evolving into carcinoid: selective effect of hormonal treatment? J Clin Pathol 39:750
102. Sunday ME, Kaplan LM, Motoyama E, Chin WW, Spindel ER (1988) Gastrin-releasing peptide (mammalian bombesin) gene expression in health and disease. Lab Invest 59:5

103. Tarle M, Rados N (1991) Investigation on serum neurone-specific enolase in prostate cancer diagnosis and monitoring: comparative study of a multiple tumor marker assay. Prostate 19:23

104. Tetu B, Ro JY, Ayala AG, Johnson DE, Logothetis CJ, Ordonez NG (1987) Small cell carcinoma of the prostate. I. A clinicopathologic study of 20 cases. Cancer 59:1803

105. Tutton PJ, Barkla DH (1987) Biogenic amines as regulators of the proliferative activity of normal and neoplastic intestinal epithelial cells (review). Anticancer Res 7:1

106. Van der Gulden JWJ, Kiemeney LALM, Verbeek ALM, Straatman H (1994) Mortality trends from prostate cancer in The Netherlands (1950-1989). Prostate 24:33

107. Van der Kwast TH, Schalken J, Ruizeveld de Winter JA, Van Vroonhoven CCJ, Mulder E, Trapman J (1991) Androgen receptors in endocrine-therapy-resistant human prostate cancer. Int J Cancer 48:189

108. Van Haaften Day C, Raghavan D, Russell P, Wills EJ, Gregory P, Tilley W, Horsfall DJ (1987) Xenografted small cell undifferentiated cancer of prostate: possible common origin with prostatic adenocarcinoma. Prostate 11:271

109. Wasserstein PW, Goldman RL (1979) Primary carcinoid of the prostate. Urology 13:318

110. Wasserstein PW, Goldman RL (1981) Diffuse carcinoid of the prostate. Urology 18:407

111. Willey JC, Lechner JF, Harris CC (1984) Bombesin and the Cterminal tetradecapeptide of gastrin-releasing peptide are growth factors for normal human bronchial epithelial cells. Exp Cell Res 153:245

112. Winkler H, Fischer Colbrie R (1992) The chromogranins A and B: The first 25 years and future perspectives. Neuroscience 49:497

113. Zalatnai A, Paz Bouza JI, Redding TI, Schally AV (1988) Histologic changes in the rat prostate cancer model after treatment with somatostatin analogs D-Trp-6-LH-RH. Prostate 12:85 